\title{
Is Anyone Minding Stonehenge? The Origins of Cultural Property Protection in England
}

\author{
Joseph L. Sax门
}

This Article is the second in the author's ongoing series of articles on cultural property protection. In this Article, the author examines the genesis of preservation policies in the United Kingdom. The mid- to late eighteenth century witnessed a development boom that threatened many of the ancient ruins of England. Sir John Lubbock introduced a bill in Parliament to provide for the preservation of such ancient monuments. The author traces the history of this bill, thoughtfully exploring the origins of the concepts of cultural heritage property. Specifically, Lubbock's goal was responsible stewardship by proprietors and the government, and his views were eventually vindicated in legislation enacted to protect ancient monuments.

\section{INTRODUCTION}

As children of an age of individualism, we are taught that it is not the task of government to inake us good. Yet we have created a culture that designates public artifacts ranging from the contents of the art inuseum and the library to the grizzly bear, Grand Central Station, and Mesa Verde National Park. The public designation trnmpets a message: This object is important. That sculpture is art. These ruins are worth saving. Most of the time we hardly seem aware that we have surrounded ourselves with official icons. And when, as occurs from time to time, the issue is thrust upon us-as with controversy over "Western civilization" courses in the universities ${ }^{1}$ or public subsidy of sexually explicit art ${ }^{2}-$ even then the response tends to be a sharply focused debate on racial or free speech issues rather than an inquiry into the propriety and significance of cultural policy in the modern state.

Preservation, the focus of most cultural pohicies, is not itself a

$\dagger$ James H. House \& Hiram H. Hurd Professor of Law, Boalt Hall School of Law, University of California, Berkeley. A.B. 1957, Harvard College; J.D. 1959, University of Chicago.

1. See D. D'Souza, Illiberal Education: The Polmís of RaCe aNd SEX on CaMpus (forthcoming 1991); Atlas, On Campus: The Battle of the Books, N.Y. Times, Jime 5, 1988, § 6, at 24 , col. 1 .

2. See Glueck, Art on the Firing Line, N.Y. Times, July 9, 1989, § 2, at 1, col. 2; Kramer, Is Art Above the Laws of Decency?, N.Y. Times, July 2, 1989, § 2, at 1, col. 1. 
modern idea. Some things have always been treasured and passed along from one generation to another because they were thought beautiful or sacred, or because they memorialized some important event. So long as preservation consisted of purely private acts, in the context of art collection or the perpetuation of family tradition, or acts performed as kingly prerogatives or rites within a religious institution, preservation presented no difficulties for political theory. But once preservation is conceived as a duty of the inodern state, it becomes necessary to ask what that duty is. It is a curious fact that we now have policies of historic, natural, and cultural preservation in abundance, but we have hardly anything that resembles a theory of public preservation policy.

How did we get liere? One way to approach the question is to look to the genesis of such policies in the modern world and ask what circumstances gave rise to proposals for preservation, how such claims were justified, and what opposing concerns were raised against those claims. I have begun sucl an inquiry in a projected series of articles of which this is the second. The story, put simply, describes the endeavor to build a perspective of time into public policy, to institutionalize the long view, and to einploy preservation not as a glorification of the past but as a promise to the future that the present will not impoverish it. In selecting the artifacts it wishes to pass on, preservation policy goes beyond simply saving certain objects and becomes a symbolic shaping of the national agenda. It serves as a banner armouncing what the nation represents, or at least what it aspires to represent.

In the earlier article, I traced the origins of preservation policy as a reaction against the iconoclasin of the French Revolution. ${ }^{3}$ In the setting of the French Revolution, the crucial effort was directed toward saving great works of art from both official and popular iconoclasm: art should be presented as the achievement of the artists' genius, their gift to posterity, rather than as the tainted product-as the iconoclasts would have had it-of the creators' association with a corrupt monarchy or a discredited religious hierarchy. The Abbé Grégoire, a prominent member of the Revolution's Committee of Public Instruction, succinctly stated this view by asking those who were throwing down the statues of kings and the sculpture of the cathedrals: "Because the Pyranids of Egypt had been built by tyranny and for tyraimy, ought these inonuments of

3. Sax, Heritage Preservation as a Public Duty: The Abbé Grégoire and the Origins of an Idea, 88 Mich. L. REV. 1142 (1990). Though there is a long history of royal and aristocratic interest in preservation, protective laws are essentially a product of the inineteenth century. England was among the last of the European nations to adopt historic monument legislation. A detailed study of the subject is G. Brown, The CARE of ANCIENT MonUments (1905). A brief review of the history of legal controls appears in $1 \mathrm{~L}$. Prott \& P. O'KeEFe, LAW aNd the CulturaL HeRTTAGE: DiscoverY aND ExcaVation 31-81 (1984). 
antiquity to be demolished?" "4 His goal was not only to bind the new republic to the greatness of its past, but to repudiate the distorted simplifications of revolutionary rhetoric which, by equating the destruction of all "tainted" works with the promotion of equality and liberty, seemed to lionor what Grégoire called "the axioms of ignorance."

The events described in this Article pick up a parallel theme in a different setting. A boom of development in the mid- and late eigliteenth century threatened many of the ancient ruins of England, which were then mostly held in private ownership. The underlying claim, made in the form of proposed protective legislation, was that as owners for only a inoment in historic time, the proprietors were trustees of something that did not fully belong to them. The proponents of early historic preservation legislation began looking at objects in a novel way, shifting the focus away from the individual who unqualifiedly owns a space on the Earth and whatever things liappen to sit in that space, to a community existing in time, nourished by tlose achievenents of centuries of art and science that are often embodied in physical artifacts.

The proponents of protective legislation offered a radically new way of conceiving of property which lias become, though unself-consciously, the inodern sensibility: we see an historic inansion or an ancient redwood as not just a commodity owned by a proprietor, but as patrimomal property thiat in soine respects "belongs" to the nation and to posterity. That we commonly conceive of things in this way is due to the transformation in thinking brouglit about by pioneers of preservation thcory. The individuals wlio blazed these trails are all but forgotten. The pages that follow describe the achievernents of one of thein, Sir John Lubbock.

\section{SiR John LubBock: FAther of The ANCIENT Monuments BILL}

On February 7, 1873, Sir John Lubbock, a Mernber of Parliament for Maidstone, introduced into the House of Commons wliat miglit liave seeined the inost innocuous of legislative proposals, "A Bill to Provide for the Preservation of Ancient National Monuments." The problein the bill addressed was the observed loss of antiquities, mostly Roinan and prehistoric renams tlrat were being disinantled for their stones or plowed under for lousing developinents. Despite their historic and scientific importance, these remams were to ordinary observers just mounds,

4. Sax, supra note 3 , at 1155 (quoting H. GREGoIRE, Troisième rapport sur le vandalisme, in 2 OEUVRES DE L'ABBE GrEGoIre 335, 352 (1977)).

5. Id. at 1145 (quoting $\mathrm{H}$. GREGOIRE, Nouveaux développements sur l'amélioration de l'agriculture, par l'établissement de maisons d'économie rurale, in 2 OEUVRES DE L'ABBÉ GREGOIRE, supra note 4, at 119, 132).

6. A Bill to Provide for the Preservation of Ancient National Monuments, February 7, 1873, 36 Vict., Bill 5 (unenacted) [hereinafter Ancient Monuments bill]. The history of the bill is briefly recounted in G. Brown, supra note 3, at 152-54, and W. KenNET, Preservation 22-30 (1972). 
ditches, or piles of stone with neither aesthetic nor utilitarian value. Almost all the sites in question-including celebrated ones like Stonehenge-were privately owned, and they had no legal protection whatever.

Sir John Lubbock, the chief sponsor of the bill, was no ordinary legislator. He was a particularly talented example of that species of gentleinan scientist his century produced, a banker by profession, and the son-in-law of General Augustus Henry Pitt-Rivers, the doyen of Victorian archaeology. During his lifetime, Lubbock was one of the bestknown men in England. He was a neighbor and protégé of Darwin. He wrote a number of popular books on entomology, anthropology, and botany.

Yet Lubbock's concern for the preservation of prehistoric reinams was not a passing interest. He first gamed an international reputation through his work on the information that archaeological remains provide about human beginnings, and he wrote a book, Pre-Historic Times, that brought together the available data on the life of prehistoric inan in Europe and America. His involveinent in this field was inore than merely detached and professional. He personally saved what hittle reinamed of Avebury (soinetimes called Abury), the site of the largest ancient monument erected in Britain, which once had been even grander and inore important than Stonehenge. In a letter to a friend, Sir John wrote:

You asked me about the narrow escape which Abury had. You will remember that the vallum which encloses an approximately circular space of nearly 30 acres is divided into quarters by two roads, which meet almost in the middle. One of these quarters was sold to a building society, which resold it in cottage allotments. Of course, if cottages had been built there the general effect would have been entirely destroyed .... . Various letters appeared in the Times and other papers, but it was no one's business to interfere. At last Mr. King, the rector of Abury, wrote to me in despair. ... I at once telegraphed to Mr. King to buy the ground for me, which he did ....7

Lubbock's observation that "it was no one's business to interfere" became the centerpiece of his long struggle to obtain enactment of the Ancient Monuments bill. National inonuments, he said during one of the debates on his proposal,

7. C. KaIns-Jackson, OuR ANCient Monuments and the LAND ARound Them 52 (1880). To ensure protection of the whole of Avebury, an appeal was made in 1937 to acquire the land for the nation. In support of the appeal, one proponent said that " [i]f it is agreed that to preserve Avebury is to safeguard a great national heritage for all time, it surely follows that the cost should be a national responsibility.' " A. BURL, PREHISTORIC AvebURY 56 (1979) (quoting Clark, The Preservation of Avebury, 3 Proc. PrehIST. SOC'Y 467 (1937)). But the Treasury offered nothing, as if in a final rebuff to Lubbock. In 1942, the nongovernmental National Trust for Historic Preservation became responsible for Avebury and inuch of its surroundings. Id. 
have generally been sacrificed, from ignorance of their value and interest, for the inost trivial reasons. They have been carted away to inanure the ground, or broken up to inend the roads. At present there is no one who has the right, in the name of the nation, to say a word to prevent such acts of Vandalisin. ${ }^{8}$

The cause required "soine authority, who, speaking in the name of Parhament and his countrymen," could condemn such acts as "desecrat[ion]" of national values. 9 The purpose of the Lubbock bill was to provide that authority.

\section{The BuLl AND RESPONSES TO IT}

Sir John drafted his bill to be as uncontroversial as possible. It established a commission with authority to designate important antiquities as ancient inonuments. The owners of any such designated inonuinent would thereafter be obhgated to notify the government, and offer it the inonument for purchase, before undertaking construction on the site. If the government decided not to exercise its right of purchase, the owners were free to go forward with their work. The owners were entitled to full compensation. Last, in order to mtrude as hittle as possible on the private hives of the landowners, all inhabited places, dwellings, gardens, and parks were excluded froin the bill's coverage.

Despite its seeming restramt, the Ancient Monuments bill generated a fire storm of opposition. Sir John pressed unsuccessfully for its enactment every year for ten years. When a monuments law finally passed in 1882 , it had been stripped of its strongest provisions, concerning notice and compulsory purchase. Under the bill that was finally enacted, the government could do no more than purchase froin a willing seller should the Treasury deign to provide any money for that purpose, accept the role of gnardian of designated monuments at the behest of an owner, or accept monuments deeded or willed to the government by private owners. ${ }^{10}$

Why was the Lubbock bill so controversial? It was certainly not the subject matter, as antiquities were greatly prized by the Enghish. ${ }^{11}$ For

8. 266 PARL. DEB. (3d ser.) 885 (1882).

9. Id. at 885-86.

10. Ancient Monuments Protection Act, 1882, 45 \& 46 Vict., ch. 73, §§ 2-4. For subsequent amendments, see infra notes $89-90$ and accompanying text.

11. Although the science of archaeology only dates back to the early nineteenth century, see G. DaNIEL, A HuNDREd AND FifTY YeARS OF ARCHAEOLOGY 28 (2d ed. 1975), English interest in antiquities goes back at least to the time of Heury VIII, who appointed John Leland as "King's Antiquary." Like the rest of Europe, England fell under the spell of the Renaissance, which kindled its interest in classical antiquities. See J. Evans, A History OF THE SocIETY OF ANTIQUARIES 3, 15 (1956). By the eighteenth century, antiquarian iuterest focused almost exclusively on the classical age, and the art of the Middle Ages was held in low regard. The art of that era had to await the early nineteenth-century Gothic revival, promoted by such literature as the novels of Sir Walter Scott. $C f$. 
well over a century, British expeditions had scoured the Mediterranean in search of classical treasures. Lord Elgin's famous-or notoriouscapture of the Parthenon inarbles was already sixty years past. ${ }^{12}$ The British Museum was an avid purchaser of artifacts of the ancient world. And the British were second to none in their admiration for the monumental achievements of medieval civilization. While it is true that indigenous artifacts were among the last antiquities to gam appreciation in Britain as elsewhere, ${ }^{13}$ and that archaeology was still a new science in the $1870 \mathrm{~s},{ }^{14}$ there was near-unanimous agreement by the time of the bill's introduction that the remams of the nation's prehistoric past were of inestimable value. Hardly anyone disputed the worthmess of the goals of the Ancient Monuments bill; it was the legislation's mechanisn1 for achieving those goals to which people objected.

Lubbock expressed astonishment that his proposal should give rise to such fierce opposition, and he insisted there was in principle nothing novel in it. ${ }^{15}$ He sought to reassure his opponents that the law was entirely equitable toward property owners, for it assured then full and fair compensation for any economic loss they might suffer. ${ }^{16}$ Nor could they complain about the bill's compulsory purchase provision; the power of eminent domam had been imdisputably established, as illustrated by national defense and railway condemnation legislation. ${ }^{17}$ Neither would the bill ever be invoked to impede any major developnients; indeed, one of the strong poimts in its favor was the evidence that priceless antiquities were inost often deniohshed for purposes as trivial as the provision of

Davies, The Preservation of Ancient Monuments, 20 J. Royal INST. BRIT. ARCHITECTs 533, 543-44 (1913) (noting that the same eighteenth-century antiquarians who actively promoted the study of classical antiquity despised medieval remains).

12. See generally W. St. Clair, LoRd Elgin AND THE Marbles (1983) (describing Lord Elgin's acquisition of marble sculptures from the Parthenon).

13. See Smith, The British Museum and British Government Attacked, in THE WORLD OP THE Past 327, 327-28 (J. Hawkes ed. 1963) (reprinting an 1856 article). Smith had urged the British Museum to acquire a collection of Anglo-Saxon artifacts, which were offered at a very modest price. Although I could not be ignorant of the indifference with which our national antiquities have been and are regarded by the Government,... I advised that the collection should be offered to the Nation, through the Trustees of the British Museum. This was done; and an extremely moderate sum was asked. . . . The Trustees, however, did refuse the offer. . . . [T] he Nation, consequently, was not to possess a most extraordiuary collection of the rarest monuments ..... Id.

14. See generally G. DANIEL, supra note 11 (describing the birth and evolution of the science of archaeology).

15. See J. Lubbock, Addresses, Polmitical AND Educational 163-66 (1879). He dismissed as minor the common objections to the bill: it did not select the appropriate monuments, it should have included medieval structures, it would be costly to the Treasury, and it vested too much power in the Commissioners, who could select additional monuments for protection. Hc also dismissed any "legal and technical objections." Id. at 164-66. (By this he likely meant to allay fears of clumsy drafting and possible loopholes in the legislation.)

16. See 232 Parl. Deb. (3d ser.) 1557 (1877); 218 Parl. Deb. (3d ser.) 576 (1874).

17. See J. LubBock, supra note 15, at 163; 237 PARL. DeB. (3d ser.) 1978-79 (1878). 
paving stones. ${ }^{18}$

Perhaps Lubbock was just being disingenuous in order to inove his legislation along. Perhaps he was so eager to save the antiquities he cherished that he failed to see the true significanee of his bill. In fact, his bill marked a radical turn in the developinent of property law. His was the first piece of legislation in the Anglo-American world ${ }^{19}$ to embrace two related principles: that the protection of cultural property was a governmental duty, and that public ownership and control should be brought to bear on unwilling proprietors. The Ancient Monuments bill shifted the line between public and private authority a considerable distance for that time. A Meinber of Parhament expressed the conteinporary dissatisfaction with the Lubbock bill, as experienced by the proprietor of Stonehenge: "[He] had done his best to protect that 'ancient monument,' and ... objected to having the jurisdiction over his own property taken out of his hands."20

Sir John never ceased to insist that this view misunderstood the effect of his bill, and that the only conceivable right it took away from owners was "the childish pleasure of destruction."21 The bill left untouched all ordinary uses and rights of ownership. It permitted public intervention only if an owner set out to destroy what virtually everyone agreed should be preserved. And even then it coinpensated for whatever economic benefit the destruction and subsequent developinent would have produced.

What was missing from Lubbock's defense of the bill was the recogintion that his legislation attacked a central premise of the private property systein: whatever values inhered in property, private proprietorship was a sufficient institution to ensure their protection. No government action was necessary to remind the citizenry of its duties. Not everyone phrased criticisin of this aspect of the bill as crudely as Sir William Harcourt, who said: "It was wonderful to see how some hon. Members sank all their ordinary principles whenever one of their peculiar hobbies

18. See 266 Parl. Deb. (3d ser.) 885 (1882).

19. There was reference in the debates to an earlier law, the Irish Church Act, 1869,32 \& 33 Vict., ch. 42 , which provided that when any church or ecclesiastical building deserved to be "maintained as a national monnment by reason of its architectural character or antiquity, the Commissioners shall by order vest [it] in the secretary of Commissioners of Public Works in Ireland, to be held by such secretary ... upon trust ... to be preserved as a national monument ...." Id. $\S 25$. The properties in question were already publicly owned and therefore did not present the issue that particularly troubled Lubbock's opponents, the involuntary shrinking of private jurisdiction in favor of some sort of public duty.

20. 237 Parl. Deb. (3d ser.) 1983-84 (1878); see also 232 Parl. Deb. (3d ser.) 1550 (1877) (statement of Mr. B.B. H. Rodwell) ("[T]lere could not be a shadow of a doubt that this was a distinct interference never before attempted with the rights or enjoyment of private property.").

21. J. LUBBock, supra note 15, at 163. "[U]uless the owner of any monument wishes to injure or destroy it, this bill will not in any way interfere with him. It deprives him of nothing but the childish pleasure of destruction." Id. 
was affected. ... [One] became a Communist, put on the red cap, and said that private property was nothing to him."22

It was not necessary to take such a harsh view to recognize that Lubbock's bill raised a profound and novel question. What was this communal imperative that could not safely be left to individual owners acting independently and autononously, and that promised a nuch enlarged role for government?

\section{Defense of The Bill Against Its OpPonents}

Lubbock urged that his bill was no more intrusive than ordinary emment donıain, which was an accepted government power. He was certainly correct that his bill was in one respect parallel to other eminent doniain laws. In this case, as in others, the government acquired property from an unwilling private owner $\dot{n} 1$ order to advance a public goal. To that extent, his bill broke no new ground. But in another sense tlie Ancient Monuments bill was pathbreaking, and the differences between it and conventional eminent doniain laws were far nore significant than were the similarities.

For example, when the state takes land for a military fort or a higlway, it is not expressing disapproval of the owner's nianagenient of the land. The proprietor may be a farmer. The government lias no objection to the use of the land for agriculture. The problem is simply that the farm is in the path of a highway or railway line. The landowner has done nothing wrong but is simply in the wrong place at the wrong time.

The Ancient Monuments bill, conversely, autliorized the taking of land to allow the government affirmatively to veto tlie owner's desires. It did not simply involve a conflict over space, but a conflict of agendas about the right use of land or other property. Conventional use of the power of eminent doniain, tlrough it increases the physical scope of public ownership, does not cast doubt on the property systeni's general conmitnient to private dominion over the appropriate uses of land. It does not suggest the existence of a public progranı unbounded by conventional public functions such as transportation or defense. The Lubbock bill invoked the quite different picture of an expanding government witl an open-ended cultural program.

The opposition sought to illustrate the significance of the difference by asking what limits could be placed upon the principle einbodied in the Ancient Monuments bill. If it was appropriate for governinent-rather than the owner of the land-to decide the fate of a Roman canip or a prehistoric nound, why should not government soon be deciding tlie fate

22. 223 Parl. Deb. (3d ser.) 900 (1875). 
of a great many other things? As the Attorney General, Sir John Holker, put it:

If they adopted the principle of the Bill in this respect, where was its application to cease? If they were going to preserve at the expense of private rights everything which happened to be of interest to the public, why slould they confine the legislation to those ancient monuments? ... Why should they not equally provide for preservation of the inediaeval monuments-of those old abbeys and castles which were quite as interesting as the Druidical remains? And why should they stop even there? Why not impose restrictions on the owners of pictures or statues which might be of great national interest? If the owner of the "Three Marys" or of Gainsborough's "Blue Boy" proposed to send it out of the country, were they to prevent him, on the ground that the matter was one of national concern? If they said that a certain circle of stones was of such national interest that an interference with private rights was justifiable in order to preserve it, imight they not also say that a certain row of beech trees on a man's estate which gave great pleasure to persous passing by ought in the same manner to be preserved ${ }^{23}$

It took less than a hundred years until the fanciful examples the Attorney General put forward became common realities. The government of England does provide for the preservation of medieval structures, ${ }^{24}$ restrict the exportation of famous paintings, ${ }^{25}$ and preserve forests. ${ }^{26}$ England also has a special and extensive law that permits the adoption of "tree preservation orders," precisely to protect features such as rows of aesthetically pleasing beech trees. ${ }^{27}$ Nonetheless, the Attorney General's argument must have had some force, given that some of the specters he raised still have not come to pass:

23. 232 PARL. Deb. (3d ser.) 1542-43 (1877); see also 223 PARL. DEB. (3d ser.) 899-900 (1875) (where the Attorney General made similar argument). The Attorney General was the spokesman for the Disraeli government, which opposed the bill. In 1880, the Conservatives were defeated and Gladstone, who perhaps was more sensitive to shifting public opinion, came into power. W. KENNET, supra note 6, at 26-27. In 1881, the year before the watered-down bill was enacted, Lubbock did get the government to agree in principle to the goal of his bill, through passage of a motion stating that it was "desirable that the Government should take steps to provide for the protection of ancient monuments." Id. at 28.

24. See, eg., National Heritage Act, 1983, ch. 47, 32 HALSBURY's STATUTES OF ENGLAND AND WALES 391-406 (4th ed. 1987).

25. See generally 3 L. ProtT \& P. O'Keefe, Law and the Cultural Heritage: MOVEMENT If 941 (1989) (outlining the British hicensing system, which regulates the export of antiques, including works of art). British policy grows out of H.M. TREASURY, REPORT OF THE COMMITTEE ON THE EXPORT OF WORKS OF ART ETC. (1952), known as the Waverley Report.

26. See, e.g., National Parks and Access to the Countryside Act, 1949, 12, 13 \& 14 Geo. 6, ch. 97, 32 HALSBURY'S STATUTES OF ENGLAND AND WALES 67-132 (4th ed. 1987). The Act provides for compulsory purchase authority. Id. $\$ \S 17-18,32$ HALSBURY's STATUTES OF ENGLAND AND WALES 81-82 (4th ed. 1987).

27. Town and Colnitry Planning Act, 1971, ch. 78, $\$ 60,46$ HALSBury's STATUTES OF England AND Wales 342 (4th ed. 1987); see Davies, Compensation Under Tree Preservation Order: Bell v. Canterbury City Council, 1 J. ENVTL. L. 90 (1989). 
It might be very desirable that the nation should possess the best pictures and statues, and other works of art, many of which were quite lost to the public from being in private collections . . . but would they justify the acquisition of them in such a compulsory manner as that now proposed? $^{28}$

The assumption under which the Attorney General operated was that the objects he mentioned were preeminently private and thus should be at the disposal of imdividual owners. That certainly was the cominon understandimg of the time, so much so that it was apparently thought sufficient merely to offer telling examples to show the flawed principle in the Lubbock bill. Sir John Lubbock himself repeatedly insisted that he supported no such broad principle. But his opponents had the better of the argument. Whatever principle justified a public takeover of Stonehenge was no less apphicable to a medieval manor or an ancient grove of trees. The Lubbock bill had to stand or fall on some large claim in favor of collective policies displacing the individualistic, decentralized, and autonomous system of private property that existed in the late nineteenth century.

Sir John did not want to meet the opposition directly on the claim that the bill would establish a new and very expansive principle of public involvement in private property. Instead, he and his allies pressed hoine the "no right of destruction" point:

If an owner of an ancient monument was not going to injure it, but, on the contrary, would take every care of it, the Bill did not apply. All that the Bill called upon the Commissioners to do was to watch the inonuments named in it, and only to act when the owners proposed to injure any of them. Would any hon. Gentleman say it was not within the province of Parliament to interfere with the proprietor of a inonument like Stonehenge, if he tried to pull it down? ${ }^{29}$

Framing the issue im this way put tlie bill's opponents in a most awkward position. Virtually no one was willing to say it would be a matter of imdifference if sucli monuments disappeared. Nor could it be seriously asserted that the bill was unnecessary. While opponents urged that most landowners were responsible and would voluntarily care for valuable monuments on their land, ${ }^{30}$ Lubbock liad produced irrefutable evidence that a number of antiquities liad been lost due to ignorance,

28. 223 PARL. Deb. (3d ser.) 900 (1875). So far as I have been able to discover, no countries condemn paintings in private collections in order to enrich national inuseums.

29. Id. at 901-02 (statement of Mr. E. Stanhope).

30. "[I]t was a monstrous thing that a man should be put in the position-as he would be under the Bill - of affirming that he was injuring his own property, and of writing himself down a sort of enemy to the public." 237 PARL. DEB. (3d ser.) 1985 (1878) (statement of Mr. Henry Raikes); see also 232 PARL. DEB. (3d ser.) 1543 (1877) (statement of Attorney General) (saymg that he was unaware of serious interference with any ancient monuments, and that he believed the owners of such inonuments would not permit them to be damaged); W. KENNET, supra note 6, at 24-25 
indifference, or avarice. By posing the issue as whether an owner had the asserted right to destroy solnething everyone else agreed was valuable, Lubbock introduced the concept of the responsible owner. The bill's opponents saw exactly what was happening. In the debates in the House of Lords in 1880, Earl de la Warr said:

The bill in its present shape was an objectionable one; the third clause was especially so. A monument on any part of the land of a private owner was as much his property as if it were in his park, garden, or pleasure ground. Under that clause [, however,] the proprietor was dealt with not as the owner of his property, but as a mere trustee of it. They might as well deal in that way with an old picture which had an owner as with an ancient inonument which had come down to him with the family estate. ${ }^{31}$

When pressed, the bill's sponsors in effect conceded that they were redefining the rights of property to include a concept of the responsible owner:

The argument as to the rights of private property was a horse that might be ridden too hard. If the rights of private property were more respected in England than in any other country of Europe, it was because they had never been strained too far. Who did inore to ensure respeet for the rights of private property-the nobleman who generously threw open his park or his picture gallery for the benefit of the public, or the curmudgeon-for he deserved no other title-who built a high wall round his land to shut out a view of his trees in order 'not to interfere with his privacy'-which really meant the privacy of a few rabbits and pheasants? ${ }^{32}$

Lubbock's goal was never to acquire full public possession and control of cultural properties. ${ }^{33}$ The inodel he had in mind was indeed one of responsible stewardship, both on the part of proprietors and, where they faltered, on the part of the government. Thus he sought froin the

(noting the behefs of Sir Charles Legard who maintained that owners could be trusted to look after monuments on their own property).

31. C. KAINS-JACKSON, supra note 7, at 109 (quoting Earl de la Warr).

32. 232 PARL. DEB. (3d ser.) 1550 (1877) (statement of Mr. Osborne Morgan).

33. "Some, I know, have thought that we should go further, and claim for the nation the direct and immediate right of purchase. ... [I]t seems to me wiser not to interfere, unless the necessity should really arise ...." J. LUBBOCx, supra note 15, at 164 .

Such restraint has continued to be British policy. The Waverley Commission Report, though speaking of export controls and artistic treasures (rather than ancient structures), expressed a sentiment with which Lubbock would no doubt have agreed:

It was the great cognoscenti of the past who brought to this country the works which we are now concerned to kecp here. From the time of Lord Arundel and the first Duke of Buckingham in the reign of Charles I, ... English enthusiasts created a tradition of collecting which has never been excelled. ...

Such collectors-and they still exist today-play an important part in kecping works of art in this country. They also help to spread a sound appreciation and understanding of the arts. In many cases ... their collections pass into public ownership, but even when this is not the case, they form a sort of reservoir which allows the State the opportunity of 
outset to establish the principle that the government did not have merely a right to protect ancient monuments by the expenditure of money, but rather had a duty to do so. The government, while agreeing that preservation was highly desirable, was entirely unwilling to concede that it had any responsibility for preservation. Its reluctance was in part financial, for it saw the Lubbock bill as generating an open-ended deinand on the Treasury. But the government also had a principled reservation. It was just as unwilling to take on the role of trustee or steward as were the private landowners. Lubbock had no patience with this reluctance, since his very desire was to create a national authority that could prevent such destruction. $^{34}$

\section{National Heirlooms: The Dual Nature of Heritage PROPERTY}

The idea of a responsible steward suggests the presence of an interest or right held by some other party-in this case the public - that gives rise to a fiduciary duty in the steward. What was the nature of the public's "estate" in the antique objects that formed the subject of the Lubbock bill, and that were by all conventional legal standards just plain private property? The imphicit theory of the bill was that property had two distinct elements. The element that belonged to proprietors was the economic value or use value of their property. Insofar as that was taken away, the proprietors were entitled to full compensation. The inonuments had another element, however-namely, their historic and scientific value-which belonged to the nation. The idea was that the history of England, though it might in part be embedded in a physical structure, could hardly be said to belong to soine individual. In preventing the destruction of its history, the nation was not taking something away from the owner, but was safeguarding something of its own. Whether the claim was put in proprietary terms, as something "belonging" to the nation, or in some less legalistic forn, the concept was the same: The nation as a collectivity had a preexisting interest in many objects that had always been considered entirely private.

The idea of elements of cultural property that inherently belong to the public was unfamiliar and at the same time, convincing. No doubt this novelty explains why the claim for untrammeled private jurisdiction over antiquities like Avebury or Stonehenge was ultimately unpersuasive. As the bill's opponents recognized, however, the principle was pregnant

acquiring paintings gradually over a period of years, instead of being forced to do so on the first occasion when they coine on the inarket. ...

For this reason we regard it as most inportant to give the bona fide private collector as much help as possible.

Waverley Report, supra note 25, at 28-29.

34. 266 PARL. Deb. (3d ser.) 885-86 (1882). 
with expansive possibilities. Why, indeed, didn't all the great paintings in private homes now belong to the English people, naking the owners "mere trustees" of even their own ancestors' portraits?

The notion that property can have a dual nature is as intriguing as it is elusive. Even today, efforts to formulate it have a disquieting vagueness. For exainple, one commentator has written that " $[\mathrm{t}] \mathrm{h}$.re is a sense in which many old buildings are not just the private property of their owners, but also form the 'public realm', because they are part of the familiar street scene. Their destruction can create a sense of grief or anger...."35 $\mathrm{He}$ continues by observing that "what we call our heritage is in effect public property so that its neglect makes us all poorer," ${ }^{\prime 36}$ and concludes that "[i]f long established buildings and areas can be considered to some extent public property, then it follows that their owners are often in effect 'trustces' ... who have obhigations to keep the buildings in good order." 37

Despite its novelty a century ago, the dual nature of historic properties was asserted so casually and confidently in the debates over the Ancient Monuments bill that one might have thought it an established principle of law. As we shall sec presently, Lubbock was not the originator of the idea. He seems to have picked it up from the writmgs of his friend, John Ruskin, who had probably drawn upon Victor Hugo's campaign, decades earhier, against the destruction of historic inonuments in France. ${ }^{38}$ But Lubbock was the first to raise the idea in a legal context. The dual property conception inade its first appearance in parhainentary debate when Sir John rephed to the claim that his bill trespassed on rights of private property: "Hon. Meinbers had contended that the present owners had a perfect right to destroy these monuments if they chose; but surely these relics were national heirlooins, and did not belong exclusively to one generation?"39

Another Member, Mr. Osborne Morgan, put it this way:

With respect to what had been said as to the rights of private property ... these monuments were part of our national history, and as such were in a certain sense national property, and ought to be in the care of the nation quite as much as the monuments which were honsed in our museums. ${ }^{40}$

Lord Elcho picked up on this characterization with an analogy to historic documents, saying that "these ancient monuments were valuable

35. Falk, Architecture and the Built Environment: Adapting the Old, in MAKING THE MOST OF Our Herrtage? 32, 35 (1989).

36. Id. at 36 .

37. Id. at 39 .

38. See infra text accompanying notes 61-69.

39. 237 PARL. DeB. (3d ser.) 1979 (1878).

40. 223 PARL. Deb. (3d ser.) 893 (1875). 
records, and that it was the legitimate duty of the House of Commons to endeavor to preserve them for the nation." ${ }^{41}$ Others pursued the congruent proposition that there was no right of destruction. A Mr. C. Dawson asked,

Was it possible that the Government would say that it should be in the power of any person, unappreciative of those monuments, to destroy them; and that they would not inake penal the destruction of those monuments, which illustrated the history of the country? They had been told a good deal about the rights of property; but these monuments were not the property of any particular individual ....42

Still another speaker said:

No person ... certainly would propose any undue interference with the rights of private property; but their ancient inonuments, while in a certain sense private property, were at the same time subjects of public interest ... [and thus could not simply be left to] the possession of persons who were totally incapable of appreciating their value, and totally regardless of their preservation. ${ }^{43}$

\section{NATIONAL HEIRLOOMS: SOURCES OF AN IDEA}

What is the derivation of the concept that cultural property has a dual nature and that its owners should therefore be viewed as guardians and not merely as masters? There is no easy answer, not only because the Lubbock bill's proponents cited no authority for their assertions, but also because the concept has no obvious source. Lubbock and his colleagues were putting forward a novel proposition. Yet it is possible that Sir John was drawing upon some earher thread of property law.

A prime candidate for a possible conceptual precedent is the legal status of the crown jewels. They are technically "heirloom" property, the very word Lubbock used to describe ancient monuments. Heirloom status in Enghish law ineans that an itein of property inust pass to the owner's heir, and the owner has no power to leave it to anyone else. ${ }^{44}$ While the heirloom idea is primarily a practical one to protect the integrity of land, it has a inore symbolic importance as apphed to the crown jewels. Jewels are treated as heirlooins, Blackstone says, because "they are necessary to maintain the state, and support the dignity, of the sover-

41. Id. at 894 .

42. 259 PARL. DEB. (3d ser.) 877 (1881). This suggestion went beyond the Lubbock bill, which did not purport to regulate destruction prior to acquisition and the payment of compensation.

43. 223 PARL. DeB. (3d ser.) 911 (1875) (statement of Mr. Charles Dalrymple) (emphasis added).

44. See 2 S. Stephen, New Commentaries on the Law of England 357-59 (16th ed. 1914). Judge Stephen explains that "the termination, 'loom,' is of Saxon original, in which language it signifies a limb or member; so that an heir-loom is nothing else but a limb or inember of the inheritance." Id. at 358. 
eign for the time being."45

The crown jewels have just the sort of duality the Lubbock bill sought to recognize: use value for ordinary purposes, but also symbolic value, to represent national power, standing, or historical continuity. Under this dual conception, conventional ownership is overlaid witl a responsibility of care and preservation for the benefit of the nation in the ages to come. The parallel is not a perfect one, to be sure. Oddly enough, heirlooin status apphes only to limit power over the identity of an inheritor; it does not impose a general duty of guardianship. During his lifetime, the owner of heirloom properties might "have sold or disposed of thein, as lie might of the timber of the estate, since, as the inheritance was his own, he might mangle or dismeinber it as he pleased." fact, some sovereigus sold or melted down royal jewels to ineet economic needs, though that was not a routine practice. ${ }^{47}$ Sovereigns usually conceived of themselves as owner-guardians with a duty to pass on the property unimpaired-precisely the status Lubbock urged on private owners of antiquities.

The idea of holding certain kinds of property in a fiduciary capacity appeared in other settings, though it seems never to have been mucli developed. For example, when the question of expropriating ecclesiastical property arose during the French Revolution, Talleyrand argued that church property was not like that of private citizens. The church, he said, inerely held the property in trust for such public purposes as divine worship, charitable works, and education. ${ }^{48}$

The notion that certain things are not ordinary private property is a tantalizing one which inakes sporadic appearances in the law. ${ }^{49} \mathrm{~A}$ notable instance was when the French asked whether an individual could own rehigious rehics:

The Church . . . tried many times to define the legal status of rehics, both at the time of their greatest abundance in the fourth to eleventh centuries, and later, at a time when their scarcity brought about so much avidity, fragmentations, theft, and purchases. Neither Saint Augustine nor the

\footnotetext{
45. 2 W. BLACKSTONE, COMMENTARIES *428.

46. 2 S. STEPHEN, supra note 44 , at 358.

47. See, e.g., Babelon \& Chastel, La notion de patrimoine, 49 REVUE DE L'ART 5, 9-10 (1980) (describing the practice of certain French sovereigns).

48. E. KenNedy, A Cultural History of tHE French Revolution 146 (1989).

49. During testimony on proposed legislation in Congress to require museums to return certain Native American objects in their collections to tribes or their descendants, one witness made the following statement: "Under the common law there is a legal fiction and a inyth that the landowner owns everything embedded in the land. ... [T] in fact own dead bodies or funerary objects embedded in his soil. He has technical possession of them, but only in trust for the descendants of those materials." Native American Grave and Burial Protection Act (Repatriation); Native American Repatriation of Cultural Patrimony Act; and Heard Museum Report: Hearings on S. 1021 and S. 1980 Before the Select Comm. on Indian Affairs, United States Senate, 101st Cong., 2d Sess. 59 (1990) (statement of Mr. Echo-Hawk).
} 
popes nor the councils had a coherent doctrine on this matter .... Could one buy them like merchandise, cut them up in pieces like a gold ingot? Or was it necessary to consider them exclusively as the goods of the Christian community, reserved to places of rehion and clearly inalienable? The canons of the councils never spoke categorically for either of these doctrines; the most contradictory usages were tolerated . . . .50

The issue illuminates a point Lubbock was at pains to make: some objects are so intrinsically important to the community that they inerit special consideration. But as the foregoing excerpt indicates, no suitable legal doctrine ever developed upon which Lubbock might have relied.

Theories of nonexclusive ownership have seen extensive elaboration in other contexts, primarily where ordinary use value-ratler than iconic value-is at issue. The public right of passage on navigable rivers and the public trust right in the ocean shore, for example, are settings in which some sort of distributive justice, usually in the forn of general access to the bounty of nature, seenis the central concern. ${ }^{51}$ The various Roman categories of nonexclusive ownership are also largely of this sort, including the nonownership of wild animals and the common rights im ports, rivers, and public buildings. ${ }^{52}$ The same might be said of the tradition of the commons, where "the public highways and byways, running water and springs, ineadows, pastures, forests, leaths and rocks . . . are not to be lield by lords' . . . without regard to rights other than their own-'nor are they to be mamtained . . . in any other way than that their people inay always use them." "53

The commons and public trust properties refiect profoundly important traditions, sharing both the notion of inalienable rights inhering in the community as a collectivity, and the concept of owner as trusteeideas important to the Lubbock bill. But they are perhaps easier concepts than the idea of national heirlooms, since in those traditions the public right is vindicated by ordinary claims of physical access and use. Lubbock imight have pointed to well-recognized traditions of public use of forest commons and public navigation of rivers. He faced the additional difficulty, however, of trying to identify the objects that, though fully private in their ordinary use, somehow carried in them the "essence" of the nation. In that task he was working an untrodden field.

The specific verbal formulation tliat Lubbock used when speaking of

50. Babelon \& Chastel, supra note 47 , at 5 (translation by author).

51. For the historical background of the public trust doctrine, see Deveney, Title, Jus Publicum, and the Public Trust: An Historical Analysis, 1 SEA GRANT L.J. 13 (1976).

52. See Coquillette, Mosses From an Old Manse: Another Look at Some Historic Property Cases About the Environment, 64 CORNELI L. REV. 761, 801-03 (1979) (describing Roinan common property doctrines).

53. M. Bloch, French RuRAL History 183 (1966) (quoting The Customs OF Barcelona (c. 1070)). 
national heirlooms, now described as heritage or patrimomal property, seems not to have been consciously based on any previously existing legal doctrine. Its first expression in pohtical discourse appeared during the French Revolution, when opponents of revolutionary iconoclasin pleaded for the preservation of artistic treasures. ${ }^{54}$ "The productions of gemus and the means of instruction are common property,"55 the Abbé Grégoire said in 1793; such items are "national objects which, belonging to no one, are the property of all." 56 Of course, the properties had in fact belonged to soineone; both church- and émigré-owned properties were seized by the revolutionary state. ${ }^{57}$ Grégoire's argument, however, was broader, claiming that the nation as a civilized community should consider itself obligated to preserve thein.

Grégoire, like Lubbock, was distressed as he observed how his countrymen mistreated ancient ruins. Grégoire coined the ternn "vandalism," 58 a term used frequently by Lubbock in the parhamentary debates, to describe the negligent or willful ignorance capable of dismantling a Roman rehic or a medieval abbey for its value as paving stones. Terms like "common property" and "common heritage"s9 appeared frequently in Grégoire's discourses. The point he urged against the iconoclasts was that artistic and historic treasures were not just ordinary property but artifacts whose fate defined the nation's commitment to "civilized" values. In this sense were they "common property."

The idea of heritage property took root in France considerably earlier than in England. Paradoxically, the aesthetic idcals of the revolutionary republican Grégoire were adopted forty years later by the conservative government of the restored monarcliy, whicls in 1830 created the post of General Inspector of Historical Monunients. ${ }^{60}$ The leading spokesinan for preservation in the new generation was the writer,

54. For a recounting of this history, see Sax, supra note 3. It may well be that the opponents of iconoclasm drew inspiration from Raphael, who in the sixteenth century wrote a letter to the Pope lamenting the destruction of Roman antiquities by "those who above all others should be fathers and guardians in the defense of the poor relics of Rome." Id. at 1149 (quoting 1 A DocumENTARY HistoRY OF ART 291 (E. Holt ed. 1957)).

55. H. GrÉgoire, MEMoIres DE GREGOIRE 58-59 (J.-M. Leniaud ed. 1989) (1st ed. 1840) (translation by author).

56. H. GREGoIRE, Rapport sur les destructions opérées par le vandalisme et sur les moyens de le réprimer, in 2 OEUVRES DE L'ABBE GREGOIRE, supra note 4, at 257, 277 (translation by author).

57. F. RÜCKER, LES ORIGINES DE LA CONSERVATION DES MONUMENTS HISTORIQUES EN France 1790-1830, at 19-20 (1913).

58. See 2 The Shorter OXford English Dictionary on Historical Principles 2451 (3d ed. 1973).

59. See, e.g., H. GREGoIre, Rapport sur la bibliographie, in 2 OEUVRES DE L'ABBE GREGOIRE, supra note 4, at 199, 206-11.

60. G. BRown, supra note 3 , at 76 . 
Victor Hugo. ${ }^{61}$ In a much-reprinted essay entitled Sur la destruction des monuments en France, ${ }^{62}$ Hugo picked up and elaborated upon the idea of common heritage property. His essay addressed the same problems that Sir John Lubbock would face a half-century later, and used much of the same terminology. Hugo declared that "[a] worldwide appeal must now finally go out calling the new France to the aid of the old. Every sort of profanation, of degradation, and of ruin at once threatens what bittle remains to us of the admirable monuments of the Middle Ages . . .."63 He contimued:

It is admitted that the lovely cloister of Saint-Wandrille is cut up, piece by piece, by who knows what ignorant and avaricious proprietor who only sees in a monument a stone quarry.... [We tolerate this, yet at the same time] we go far and wide and pay dearly to ornament our museums! ... It is necessary to halt the hammer that inutilates the face of the country. A single law wonld suffice; it is only necessary that it be inade. Whatever the rights of property may be, the destruction of a historic and monumental edifice cannot be permitted to these ignoble specnlators whose interest blinds their honor; miserable creatures, and such fools that they don't even realize they are barbarians. There are two eleinents in an edifice, its utility and its beauty. Its utility belongs to its owner, its beauty to everyone. Thus to destroy it is to exceed the right of ownership. ${ }^{64}$

Hugo's dual image of property was picked up and elaborated upon in England by the art critic John Ruskin. Like Hugo, Ruskin was the most eloquent preservation advocate of his time. ${ }^{65}$ In a chapter entitled "The Lamp of Memory" in his book The Seven Lamps of Architecture, Ruskin made his case for preservation by presenting the same image that Hugo had employed: some things do not "belong" to their legal owner. ${ }^{66}$

As it happened, Ruskin and Sir John Lubbock were friends of many years' standing, and Lubbock described himself as "an intense admirer of [Ruskin's] writings." 67 In the debates on the Ancient Monuments bill,

61. See F. RUCCKER, supra note 57, at 201-02 (discussing Hugo's eloquent contributions to the conservation effort).

62. V. Hugo, Sur la destruction des monuments en France, in 2 OEUVRES COMPLÈTEs 569 (J. Massin ed. 1967).

63. Id. at 569 (translation by author).

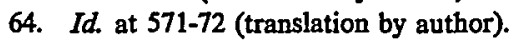

65. Ruskin's passion was for Gothic architecture. William Morris, the chief pioneer of architectural preservation in England and the founder of the Society for the Protection of Ancient Buildings, was an "ardent disciple" of Ruskin. M. BRIGGS, Got7IS AND VANDALS 203-04 (1952). Morris' work is discussed in C. Dellheim, The Face of the Past: The Preservation of the MEDIEVAL INHERTTANCE IN VICTORIAN ENGLAND (1982). The so-called "anti-scrape" movement, in which Ruskin and William Morris were leading figures and the inuch-reviled Viollet-le-Duc was the principal villain, is briefly described in D. LOWENTHAL, THE PAST Is A Foreion Country 278-82 (1985).

66. J. RUSXIN, The SEVEN LAMPS OF ARCHITECTURE (Everyman's ed. 1956).

67. Lubbock, John Ruskin, in ESSAYS AND ADDRESSES 1900-1903, at 44 (1903). 
Ruskin was the only author Lubbock quoted in support of the principle he was advancing. Lubbock quoted the following passage from The Seven Lamps of Architecture:

[I] $t$ is again no question of expediency or feeling whether we shall preserve the buildings of past times or not. We have no right whatever to touch them. They are not ours. They belong partly to those who built them, and partly to all the generations of mankind who are to follow us. The dead have still their right in them: that which they labored for ... we have no right to obliterate. What we have ourselves built, we are at liberty to throw down; but what other inen gave their strength and wealth and life to accomplish, their right over does not pass away with their death: still less is the right to the use of what they have left vested in us only. It belongs to all their successors. ${ }^{68}$

Both Hugo and Ruskin, each a master of language, have been frequently quoted for their views that preservation is a public duty, but their words have primarily appeared as rallying cries. Discerning a rationale for the claim that certain artifacts "belong" to the community, rather than solely to their proprietor, has remained elusive, even though the claim has been transformed from popular slogan to legal reality through a inultitude of statutes protecting cultural artifacts froin unconstrained private jurisdiction. ${ }^{69}$ Ruskin seems to have coine as close as anyone to fleshing out the idea, though he did so in the setting of an aesthetic theory. The ultimate account of the Ancient Monunients bill can be told as the story of the ideas that Ruskin put in the air and that Sir John Lubbock and his colleagues sought to embody in law.

\section{Ruskin’s Perspective: Objects in Time as Well as Space}

Ruskin's claim for the preservation of inedieval architecture, set out in the fainous excerpt quoted above, was certainly not put forward as a legal proposition. As a inatter of law, each point he inade was contrary to established theory. The buildings of the past did not belong either to their original builders or to "all their successors," but to the proprietor on whose land they stood. The dead did not have a claim on thein, and

68. 237 PARL. DEB. (3d ser.) 1979 (1878). The passage is found in J. RuSKn, supra note 66, at 201. Sir John Lubbock quoted the passage again in his preface to C. KAINS-JACKSON, supra note 7, at vi. Lubbock's admiration for Ruskin (though tempered by an awareness of Ruskin's irrationalities) is revealed in a talk he gave to the Ruskin Society in 1902: "In Ruskin's writings the expressions are sometimes extravagant, the facts incorrect, the opinions contradictory; but the spirit is always true and noble ...." Lubbock, supra note 67, at 53 .

69. See generally 1 L. ProtT \& P. O'KEEFE, supra note 3, at 31-81 (describing legislation on archaeological protection throughout the world). Every municipal historic preservation ordinance is an example of this conversion of a popular slogan into a legal instrument. Courts appear willing to embrace this conversion. See, eg., Pein Cent. Transp. Co. v. New York City, 438 U.S. 104, 138 (1978) (New York City's Landmarks Preservation Law valid because permitted "reasonable beneficial use" of landmark site). 
their current owners had every legal right to alter them. Yet Ruskin had drawn exactly the image for which Lubbock seems to have been searching in his effort to counter the claims of landowners.

What did Ruskin have im mind when he inade the extraordinary statement that the great medieval buildings he cherished belong to those who built them and to their successors, and that we should consider ourselves without the right to destroy them? His view was not simply that everything old is good. ${ }^{70}$ Rather, Ruskin admired the moral quality of those who built the great structures of the past, whose commitinent to the future "give[s] strength to present exertion, [and] patience to present endurance."71 Ruskin's focus was primarily rehigious and spiritual, but his ideas can be appreciated in secular terms as well. ${ }^{72}$

In the Middle Ages, a profound faith led certain individuals to devote theinselves unstintingly to the most scrupulous work of which they were capable, not for themselves but as a gift of faith and as a contribution to the faith of those who would follow them. They did not build just for themselves, but for the ages; their perspective was tine, the long run. Ruskin believed that to treat their work as casually expendable by any particular proprietor or generation was to demean it. That is what he meant when he said the work did not and should not, if we respected its makers and their sense of commitment, belong to us. It was not the buildings, but their builders, who had a claim upon us. ${ }^{73}$

Ruskin's claim on behalf of the medieval artist and artisan was not

70. With typical extravagance, Ruskin noted that "a building cannot be considered as in its prime until four or five centuries have passed over it." J. RuSkIN, supra note 66, at 198. Ruskin was no doubt influenced, however, by his view that many of the Victorian efforts at restoration, for example, the church restorations of Sir Gilbert Scott, were execrable. See M. BrigGS, supra note 65, at 170-202. In "The Lamp of Memory," Ruskin argued that "the word restoration ... means the most total destruction which a building can suffer." J. Ruskin, supra note 66, at 199 (emphasis in original).

71. J. Ruskin, supra note 66 , at 182.

72. For example, the "shifting [of] attention from the building to the builder" was described by one Ruskin critic as the author's device "to break the Catholic or High-Church monopoly on the Gothic Revival and to convince Protestants that they could enjoy both magnificent rehigious architecture and good consciences." J. SHERBURNE, JOHN RUSKIN OR THE AMBIGUITIES OP ABUNDANCE 35 (1972). The religious focus is less prominent in the later Stones of Venice than in Seven Lamps of Architecture. See J. RUSkIN, 2 THE STONES OP Venice, ch. 6, 151-230 (1880) (chapter entitled "The Nature of Gothic"). Even in the earlier Seven Lamps, Ruskin believed that "It]he importance of art or architecture . . now lies less in its symbolic suggestion of Divine attributes than in its expression of human vitality." J. SHERBURNE, supra, at 36-37.

73. For Ruskin's interest in the builders, and in the frcedom of thought and imagination their work symbolized, see J. Ruskin, supra note 72 , at 161-62. This way of thinking has a modern counterpart, in laws that recognize the moral rights of artists-in effect talking the artwork out of the category of ordinary expendable property and imposing on the owner a duty to respect the achievcinent of the artist. The owner is "reduced" to the status of a trustec or guardian. See, e.g., California Art Preservation Act, CaL. CIv. CoDe $\$ \$ 987-989$ (Decring 1990). See generally Petrovich, Artists' Statutory Droit Moral in Califormia: A Critical Appraisal, 15 LoY. L.A.L. Rev. 29 (1981) (comparing the statute to European droit moral doctrines); Comment, The Callfornia Ant 
inerely that their intentions deinanded our respect, but that their ideal of workmanship produced the inost admirable results-artistic achievement of extraordinary quality and power. ${ }^{74}$ "Ruskm regards Gothic as admirable for the reason that this style was the product of a social system which recognised the value of each individual and allowed each man to realise his human potential."75 This is quite a different view from one that simply venerates age or exalts all traditional values over modern ones. Modern work, Ruskm said, has "the look . . . of a stoppimg short wherever and whenever we can, of a lazy compliance with low conditions."76 And when one works that way, he noted, the result is selfdenigration and a sort of self-liatred. Ruskm called this "the sign[] of a great and spreading spirit of popular discontent ... when inen build in the lope of leaving the places they lrave built, and live in the hope of forgettimg the years that they have lived."77

By contrast, he esteemed tlie reinains of great works as the ultimate in commitment and tlie best of whicl humans are capable:

All else for which the builders sacrificed, has passed away-all their living imterests, and aims, and achievemerits.... Victory, wealth, autliority, liappiness-all liave departed .... But of them, and their life and their toil upon the eartll, one reward, one evidence, is left to us in those grey lieaps of deep-wrought stone. ${ }^{78}$

By conceiving of architecture as the einbodiment of the life work of its creators, Ruskm shifted tlie focus of discussion from space to time. To think of Stonelrenge in space is to see it as simply a physical thing, subject to the dommion of tlie proprietor within wliose space it is located. But to think of Stonehenge in time is to see it as something from a distant century that lias traversed the years - a part of the past that exists in the present. What lias come to us is not inerely the pliysical thing-for its physical capacity is often quite exhausted-but the lruman achievement that went into its creation. Its message of gemus and commitment remains even in a witliered and vestigial shell.

Preservation Act: Statutory Protection of Art Work Against Intentional Alteration or Destruction, 49 U. CIN. L. Rev. 486 (1980) (authored by Brian McDonough) (describing the Act's basic provisions).

74. "[O]bjects . . . become noble or ignoble in proportion to the amount of the energy of that mind which has visibly been employed upon them. ... [They] depend, for their dignity and pleasureableness in the utmost degree, upon the vivid expression of the intellectual life which has been concerned in their production." J. RuSkn, supra note 66, at 151. It is not that Ruskin thought all work of piety and devotion produced good art. His view seems to have been that commitment was necessary but not sufficient, though, as one critic observed, his artistic sensibility and his Protestant logic were sometimes at war with each other. See P. CoNNER, SAVAGE RuSKIN 79 (1979) ("Largely hidden beneath the poinpous sermonizing of Seven Lamps is Ruskin's genuine and increasing concern for the attitudes of [the constructing] society ....").

75. P. CONNER, supra note 74 , at 96.

76. J. RuSkIN, supra note 66 , at 21 .

77. Id. at 184 .

78. Id. at 28. 
It must have been easy for Lubbock, as a scientist, to see the destruction of artistic achievement as parallel to the destruction of a body of accumulated scientific knowledge, which passes through time in much the same way. That one imight own Newton's notebooks but not own the knowledge they contain, ${ }^{79}$ and that such knowledge was Newton's gift to the world through time, might be seen as a parallel to the insight Ruskin offered.

Lubbock, by analogizing ancient monuments to "national heirlooms," $" 80$ indicated that he intuitively appreciated the concept of the duality of utility and beauty, as well as the concept of objects existing in both space and time. The heirloom value of an object is entirely distinct from its use value, and its essential quality qua heirlooin is its passage from one generation to another through time. Though an individual inay own the heirloom in a full legal sense, the heirloom can equally be thought of as "belonging" to a family, whose essential identity is generational. ${ }^{81}$

Ruskin's message to Lubbock, and Lubbock's message in turn to his countrymen, was that only where there are mere stones can there be mere property. Only where there is a collectivity with nothing to say about itself as a commumity of aspiration can there be no public claim upon the masterworks of the past.

\section{CONCLUSION}

The principle of public responsibility that Lubbock urged was slow to gam acceptance, but it was finally acknowledged. It is now almost universally agreed that the state has both a right and a duty to protect cultural heritage properties, notwithstanding the reluctance of a private owner, and that the owner of such properties can no longer assert a "childish right of destruction." 82 These precepts are a legacy left us by Sir John Lubbock. While preservation as an idea had already come into its own when Lubbock put his bill forward (the government had estabhished Yellowstone National Park in $1872,{ }^{83}$ and the great Damish archaeologist Worsaae had issued his semmal report on the preservation

79. An instructive legal analogy is the incapacity to own, by way of patent, the principle underlying a scientific discovery. See O'Reilly v. Morse, 56 U.S. (15 How.) 62, 113-14 (1853) (giving the example of Robert Fulton, whose patents on steamboats would not have given him the exclusive right to all uses of steam to propel vessels).

80. See supra text accoinpanying notes $44-45$.

81. Oddly enough, though, owners had the legal right to destroy heirlooms before their death. See supra text accoinpanying notes $46-47$. In that sense, Lubbock's proposal was even more farreaching than traditional heirloom law, though it was no doubt compatible with most practice.

82. See supra note 21.

83. Act of Mar. 1, 1872, ch. 24, 17 Stat. 32 (1872). 
of antiquities ${ }^{84}$ in 1877), no one in the Anglo-American world had articulated a legal rationale for preservation legislation prior to the debates over the Lubbock bill.

No historian has yet made an effort to trace the direct influence of the ideas underlying the Ancient Monuments bill or the lessons from the threatened loss of Stonehenge or the rescue of Avebury. But some evidence suggests that Lubbock's message worked its way into the public consciousness. In 1888, a controversy developed over the fate of Kirkstall Abbey, a renowned twelfth-century Cistercian Abbey put up for sale by the aristocratic family that had owned it for more than two hundred years. To generate the highest price, the family placed no restrictions on the use of the property, and there was widespread concern that the Abbey would fall into the hands of speculators. An editorial that appeared in the Birmingham newspaper might have been written by Sir John, with Ruskin looking over his shoulder:

'A shudder must run through the mind not only of the antiquarian, but of every lover of historic art, at the announcement that Kirkstall Abbey is about to be sold by public auction. The purchaser, of course, will have the full right to do what he likes with his own, and one of the great architectural monuments of the country will be at the mercy of any chance specnlator who may think well to buy it. There ought to be some means of securing such a structure as the property of the nation, that it may be carefully preserved and left to tell its tale for future generations.... The particular abbey in question is one of the oldest and most famous of such structures ... designed and built and modified at times when Art was really a part of the national life and an exponent of the best and decpest feelings of the people. They are, indeed, national possessions $\ldots . .85$

Ultimately, Kirkstall Abbey was saved as Lubbock had saved Avebury. A local inan who had becoine very rich bought the property and presented it to the people of Leeds. ${ }^{86}$

Many more years would pass before the law finally recognized that heritage properties should be left neither to aristocratic pride nor to individual philanthropy, to say nothing of the temptation of a few shillings. ${ }^{87}$ Implementation of the specific legislative goals Lubbock sought was painfully slow. A toothless bill was enacted in 1882 , which permitted the Office of Works, with the permission of the owner, to take charge of

84. Worsaae, The Preservation of Antiquities and National Monuments in Denmark, reprinted in SMTTHSONIAN INSTITUTION, REPORTS OF THE SMTTHSONIAN INSTTTUTION FOR 1879, ANNUAL REPORT OF THE BOARD OF REGENTS 299 (1880).

85. C. DELlHEIM, supra note 65, at 106-07 (quoting Birmingham Daily Post, Aug. 20, 1988).

86. Id. at 104-05.

87. The current provision for coinpulsory purchase of ancient monuments is found in the Ancient Monuments and Archaeological Areas Act, 1979, ch. 46, § 10, 32 HalsBuRY's STATUTES OF ENGLAND AND WALES 306, 323-24 (4th ed. 1987). 
certain (sixty-eight in all) scheduled monuments. ${ }^{88}$ That law continued in force without significant change for thirty years before the government finally proposed and passed a bill allowing for coinpulsory purchase to protect monuments of national importance. ${ }^{89}$

The present law governing ancient monuments in the United Kingdom was enacted in $1979 . .^{90}$ It defines monuments very broadly as "any building, structure or work" above or below the ground, or any site comprising reinains of works, excluding only ecclesiastical buildings being used for ecclesiastical purposes. ${ }^{91}$ The basic nrechanisn of the law is identification of monuments to be included on a schedule, and the standard is "national importance."92 The Secretary of State for the Environment makes up the schedule, after consultation with the Historic Buildings and Monuments Commission-whose members are to be knowledgeable or experienced in fields such as history, archaeology, architecture, and the preservation or conservation of monuments or

88. Ancient Monuments Protection Act, 1882, $45 \& 46$ Vict., ch. 73, §2.

89. Ancient Monuments Consolidation and Amendment Act, 1913, 3 \& 4 Geo. 5, ch. 32. The impetus for the Act was the scandal surrounding the sale of Tattershall Castle. A family that had owned the castle for five hundred years sold it to a buyer who went bankrupt. The castle was then sold to an American syndicate of speculators, who started selling off individual mantelpieces to art dealers and thrcatened to pull down the whole building. See W. KENNET, supra note 6, at 32-34. In addition to broadening the definition of "monument" to include buildings other than occupied dwelling-honses and churches in nse, the 1913 Act permitted the Minister of Works to issue a Preservation Order for any monument in danger, which required the owner to obtain a consent order before doing any work of demolition, removal, alteration, or addition to the monument. Ancient Monuments Consolidation Act, $\S \S 6-8,22$. Refusal of consent could lead to a claim for compensation. See M. BrigGs, supra note 65, at 229; Davies, supra note 11, at 604. The 1913 Act also consolidated the 1882 Act with amendments passed in 1900 and 1910 . Lubbock's original bill of 1873 had explicitly excluded monuments "situate[d] in any park, garden, or pleasure ground, and which neither is nor forms part of nor includes the ruins of any castle, fortress, abbey, religious honse, or ecclesiastieal edifice." Ancient Monuments bill, supra note 6, § 3, I 2. The 1900 amendment, however, extended the authority of the Commissioners of Public Works so that at the owner's request they could become guardians over any monument not included in the 1882 law that was, in the opinion of the Commissioners, "of public interest by reason of the historic, traditional, or artistic interest attaching thereto," provided it was not occupied other than by a caretaker. Ancient Monument Protection Act, 1900, 63 \& 64 Vict. cl. 34., § 1; see also M. BRiGGS, supra note 65, at 228 (detailing the provisions of the $1900 \mathrm{Act}$ ).

90. Ancient Monuments and Archaeological Areas Act, 1979, ch. 46, 32 HalsBURY's STATUTES OF ENGLAND AND WaLes 306-82 (4th ed. 1987). The Act was amended by the National Heritage Act, 1983, ch. 47, 32 HALSBURY's STATUTES OF ENGLAND AND WALES 391-406 (4th ed. 1987). For a description of the contemporary law, see Sharman, The New Law on Ancicnt Monuments, 1981 J. PlaN. \& ENV'T L. 785.

91. Ancient Monuments and Archaeological Areas Act, 1979, ch. 46, $\S 61(7) \cdot(8), 32$ Halsbury's STATUTES OF ENGLAND AND Wales 370 (4th ed. 1987). The Act does not exelude structures occupied as dwellings (other than by a caretaker) from its definition of monuments, but it does not permit the Secretary of State to include them on the schedule of monuments. $I d . \$ 1(4), 32$ HALSBURY's STATUTES OF ENGLAND AND WALES 308 (4th ed. 1987).

92. Id. $\S 1(3), 32$ Halsbury's Statutes of ENGLAND aNd Wales 308 (4th ed. 1987 ). 
buildings, ${ }^{93}$ and whose duties are "so far as practicable ... to secure the preservation of ancient inonuments and historic buildings situated in England."94 Once a inonument is scheduled, carrying out any work that results in its demolition, destruction, or damage is an offense under the Act. ${ }^{95}$ To mitigate the potential harshness of the restriction, the statute provides a mechanisin whereby an owner may obtain consent froin the Secretary of State, following consultation with the Commission, to inake modifications on the inonument that would otherwise be prohibited in the absence of a permit. ${ }^{96}$ Where consent is denied, the statute provides for limited coinpensation to owners, principally to make them whole for losses engendered because developinent permission had already been granted before the inonument was scheduled. ${ }^{97}$ The Secretary of State also has authority to acquire any ancient monument, ${ }^{98}$ to obtain by compulsory purchase protective easements over nearby lands, ${ }^{99}$ and to provide for public access to monuments under public control. ${ }^{100}$

The regulatory and access eleinents of the current law are more farreaching than Lubbock himself envisioned, but in structure and general purpose they represent a total vindication of the principles for which he struggled for so many years. That this success was so long in coming is perhaps not surprising, for as a cominentator writing in 1913 rather gently put it, "where individualism is strongly developed, in such a country, State interference for the preservation of its monuments will be of very slow and gradual growth."101

93. National Heritage Act, 1983, ch. 47, § 32, sched. 3, 32 HaLSBURY's StatuTES of ENGLAND AND WALES 392, 402 (4th ed. 1987).

94. Id. § 33(1), 32 HALSBURY's StatUTES OF ENGLAND AND Wales 393 (4th ed. 1987). For a recent case unsuccessfully challenging the refusal of the Secretary of State to schedule the remains of a theater in which Marlowe's plays and some of Shakespeare's plays were first performed (the remains of which were concededly of national importance), see Harte, The Scheduling of Ancient Monuments and the Role of Interested Members of the Public in Environmental Law, 2 J. ENVTL. L. 224 (1990) (discussing a case before the Queen's Bench Divisional Court in 1989).

95. Ancient Monuments and Archaeological Areas Act, 1979, ch. 46, § 2, 32 HALSBURY's StatuTES of ENGLAND AND Wales 312-13 (4th ed. 1987).

96. Id. § 3, 32 Halsbury's StatuTES of ENGLAND aNd Wales 315 (4th ed. 1987).

97. Id. $\$ \$ 7-9,27,32$ HALSBURY'S STATUTES OF ENGLAND AND WALES 319-23, 341 (4th ed. 1987).

98. Id. $\S 10,32$ Halsbury's StatuTES OF ENGLAND AND WALES 323 (4th ed. 1987).

99. Id. $\S 16,32$ HALSBURY's STATUTES OF ENGLAND AND WAIES 330-31 (4th ed. 1987).

100. Id. $\S 19,32$ Halsbury's STATUTES OF ENGLAND AND WalEs 334-36 (4th ed. 1987).

101. Davies, supra note 11 , at 599. 


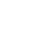

